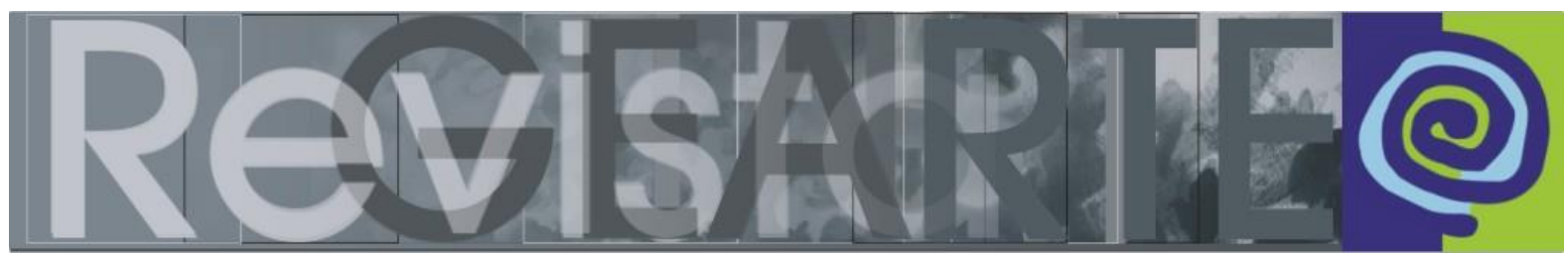

e-ISSN 2357-9854

\title{
Emoticons e Letramento Visual: Pedagogia da Imagem ${ }^{1}$
}

\author{
Ana Valéria de Figueiredo da Costa \\ (Universidade Iguaçu — UNIG, Nova Iguacu/RJ, Brasil; Universidade Estácio de Sá \\ — UNESA, Rio de Janerio/RJ, Brasil; Universidade do Estado do Rio de Janeiro - \\ UERJ, Rio de Janeiro/RJ, Brasil) \\ Isabel Almeida Carneiro \\ (Universidade do Estado do Rio de Janeiro — UERJ, Rio de Janeiro/RJ, Brasil)
}

RESUMO - Emoticons e Letramento Visual: Pedagogia da Imagem — Você está em silêncio e, de repente, seu telefone celular emite um som avisando que chegou mensagem pelo aplicativo whatsapp, popularmente conhecido com zap. Por um momento, a atividade que se realiza é interrompida. Não se lê nenhuma palavra escrita; aparece apenas figurinha (conhecida como emoji, emoticon ou smile) avisando que a resposta que se esperava é positiva. Sem nenhuma palavra escrita ou gravada, você e eu também - entendemos que tudo está bem resolvido. A partir dessa contextualização, tomando por base a força da imagem como comunicação e, ainda, a facilidade de acesso às novas Tecnologias Digitais de Informação e Comunicação (TDIC) nos dispositivos móveis, o presente artigo tem como objetivo propor reflexões sobre a utilização de imagens para a comunicação sem palavras, porém repleta de significados partilhados.

PALAVRAS-CHAVE

Emoticons. Letramento visual. Leitura de imagem.

ABSTRACT - Emoticons and Visual Literacy: Image Pedagogy - You are silent and all of a sudden your cell phone beeps warning that the message arrived from the whatsapp application, popularly known as zap. For a moment, the activity that is carried out is suspended so that the message is read, and an emoji (also known popularly as emoticon or smiley) - warns that the expected response is positive. Without any word written or recorded, you - and I also - understand that everything is well resolved. Based on this contextualization, based on the strength of the image as communication and also the ease access to the new Digital Information and Communication Technologies (DICT) in mobile devices, this article aims to propose reflections on the use of images for communication without words, but full of shared meanings.

\section{KEYWORDS}

Emoticons. Visual literacy. Image reading.

1 Parte desse artigo foi apresentado no GT 2 Educação, Cognição e Tecnologia, no III Simpósio ArTecnologia, 2016 (UERJ), mas não foi publicado. 


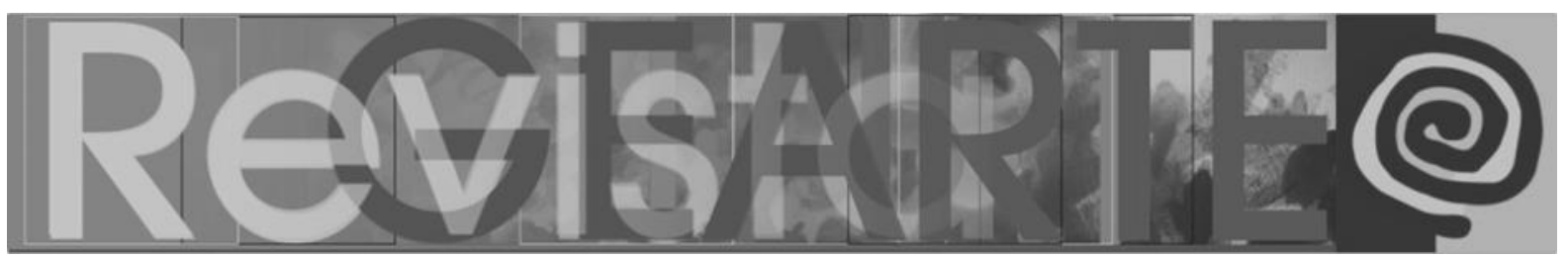

\section{O telefone fez trim...}

Quando um ícone deixa de ser uma imagem, torna-se ídolo e precisa ser sacrificado. Os iconoclastas destruíram os ícones para provar a natureza de ídolo destes, ou seja, para demonstrar a mortalidade deles. Para o Deus do iconófilo, o ícone é indestrutível. (MONDZAIN, 2013, p. 241)

Você está em silêncio e, de repente, seu telefone celular emite um som avisando que chegou mensagem. Por um momento, a atividade que estava sendo realizada é interrompida para que se possa ler o recado. Não se lê nenhuma palavra escrita; aparece apenas uma figurinha (conhecida como emoji, emoticon ou smile) avisando que a resposta que se esperava é positiva.

Figura 1 - Emoji, emoticon ou smile

Fonte: https://www.clipartmax.com/middle/m2i8b1H7b1d3m2i8_emoticon-emoji-smiley-like-buttonemoji-smiley-face-with-hands/

Sem nenhuma palavra escrita ou gravada, se pode entender que tudo está bem resolvido e encaminhado. Tomando por base a força da imagem como comunicação e, ainda, a atual facilidade de acesso às novas Tecnologias Digitais de Informação e Comunicação (TDIC) nos dispositivos móveis, o presente artigo pretende propor reflexões sobre a utilização de imagens para a comunicação sem palavras, porém repleta de significados partilhados.

Um dado relevante para isso é o conjunto de fatores que interfere no consumo relacionado ao comportamento e preferência do usuário. O número de estímulos para o consumo que cada pessoa recebe é enorme e afeta a cada um de diferentes formas em função de características culturais, sociais, econômicas, psicológicas entre outras. Nesse sentido, a tecnologia forja protagonistas mesmo que controlados pela nova aparelhagem oferecida aos diversos grupos de usuários:

Na vida contemporânea, quase tudo do pouco que conhecemos, em relação ao conhecimento produzido, nos chega via Tecnologias da Informação e Comunicação (TICs) que, por sua vez, constroem imagens do mundo. 


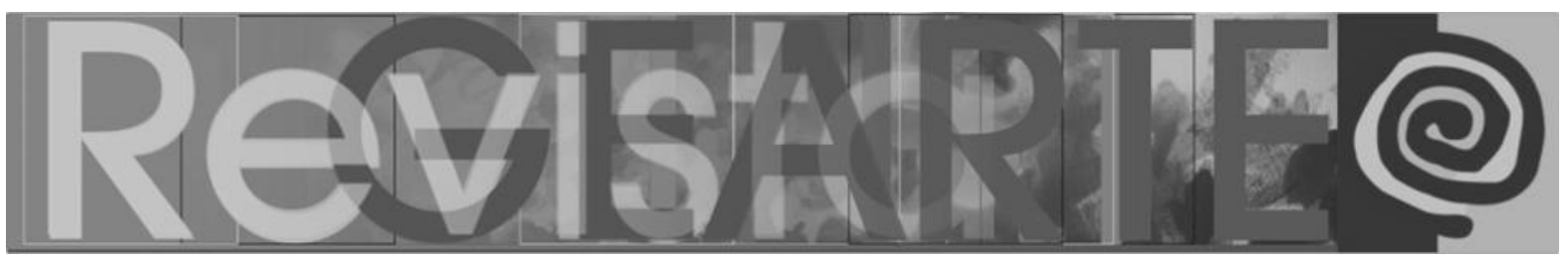

Nômades em nossas próprias casas, capturamos imagens, muitas vezes, sem modelo, sem fundo, cópias de cópias, no cruzamento de inúmeras significações. Imagens para deleitar, entreter, vender, que nos dizem sobre o que vestir, comer, aparentar, pensar (SARDELICH, 2006, p. 203).

O estudo se apoia na perspectiva do letramento visual tal como aponta Kleiman (1995) e Soares (2003), qual seja, ser letrado não significa apenas ter a capacidade de decifração desenvolvida; para além dessa definição, ser letrado é ter condições de participar do mundo da leitura e escrita como ser social, fazendo uso destas como ferramentas de ser e estar no mundo, operando e interagindo nas diversas e múltiplas relações sociais.

Pensando que a imagem é comunicação em estado pictórico, ser letrado imageticamente é também uma importante habilidade para as relações interpessoais e acadêmicas. Dessa forma, concordamos com Rodrigues (2015, p. 85) quando aponta que "o termo letramento se refere, aqui, ao uso crítico, social e simbólico daquilo que decodificamos: um texto, uma imagem, uma música, um gráfico etc.".

O letramento ultrapassa a ideia de decodificação, de instrumentalização de leitura pelo código: supõe o uso de um sistema simbólico, ou seja, de sinais estabelecidos socialmente e que podem ser entendidos também socialmente. Esse ponto de vista é completado com os contextos nos quais se inserem as interlocuções entre os sujeitos comunicantes. Além da dimensão simbólica, os aspectos da tecnologia dessa comunicação também estão presentes no processo de letramento, visto que esses processos de escrita são operados através de gêneros e suportes diversos, que tomam diferentes feições e materiais ao longo dos tempos históricos.

Os sistemas simbólicos e tecnológicos operam conjuntamente conforme ressalta Kleiman (1995), visão que é partilhada por Soares (2003) quando defende a indissociabilidade desses campos tanto na teoria, quanto na prática. Nesse sentido, a leitura de imagens torna-se ponto fulcral nos processos de comunicação utilizando TDIC e se agudizam com a utilização dessas mesmas TDIC nesses processos contínuos de fluxos de comunicação. 


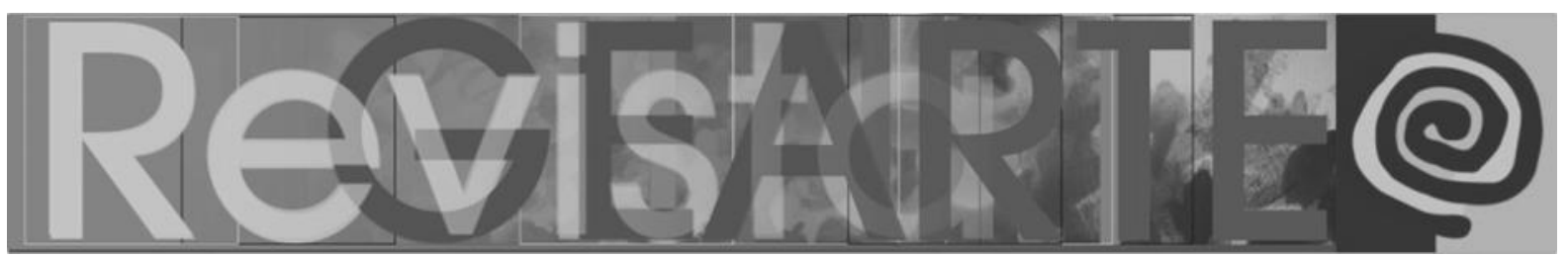

Sob essa perspectiva, Aumont (1993, p. 78) sugere que "a produção de imagens jamais é gratuita, e, desde sempre, as imagens foram fabricadas para determinados usos, individuais ou coletivos". Portanto, pode-se conceber uma imagem como instrumento mediador entre o espectador - aquele que olha - e a realidade daquele que a vive enquanto a frui. Segundo o autor citado, espectador é "aquele sujeito que olha a imagem, aquele para quem ela é feita" (AUMONT, 1993, p.14). Ou seja, há sempre uma intencionalidade no dizer da imagem. Porém a leitura que se empreende é polissêmica e permite várias e múltiplas entradas nos sentidos do texto.

Complementando essa ideia, é interessante trazer o que diz Vilches ${ }^{2}$ (1984, p. 95-96):

[a leitura do texto visual] se trata de um ajuste, de um convênio entre os interlocutores, pelo qual cada um (emissor e destinatário) é - pode ser diligente e cuidadoso, tanto na ação quanto na negociação do texto. [...]. Esta matéria - que é o texto - base da comunicação de massas não é de maneira nenhuma fortuita ou eventual: o autor ou emissor prevê as diferentes opções a quais submeterá seu produto ao leitor ou destinatário.

Ao expandir essa noção de espectador, percebemos que uma imagem extrapola o visível ou o legível, algo que nos exige um esforço, que nos violenta, por isso Didi-Huberman (1998, p. 29) afirma que as imagens são capazes de nos olhar ${ }^{3}$ : "o que vemos só vale - só vive - em nossos olhos pelo que nos olha. Inelutável, porém é a cisão que separa dentro de nós o que vemos daquilo que nos olha". A imagem dialética e instigadora se constitui com a interpenetração "crítica" do passado e do presente, sintoma da memória coletiva e inconsciente. $E$ a imagem por ser coletiva e inconsciente pode ser interpretada por quem produz e por quem a lê: "e eis que surge

2 Tradução livre do trecho: "se trata del ajuste de um convenio entre dos interlocutores, donde cada uno (emisor y destinatario) es - puede ser - diligente y cuidadoso, tanto em laacción como enelefecto de negociacióndel texto. [...] esta materia - que es el texto - base de la comunicación de masas no es, de ninguna manera, fortuita o eventual: el autor o emisor prevélas diferentes opciones a las que someterá suproducto ellector o detinatrio. (VILCHES, 1984, p. 95-96).

3 Didi-Huberman "O que vemos, o que nos olha" (1998).

COSTA, Ana Valéria de Figueiredo; CARNEIRO, Isabel Almeida. 70

Emoticons e Letramento Visual: Pedagogia da Imagem.

Revista GEARTE, Porto Alegre, v. 6, n. 1, p. 67-79, jan./abr. 2019.

Disponível em: http://seer.ufrgs.br/gearte 


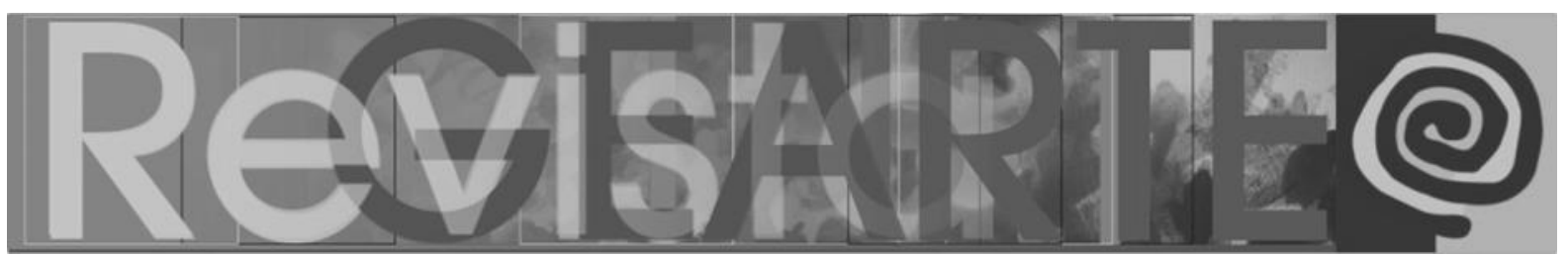

a obsedante questão: quando vemos o que está diante de nós, por que uma outra coisa sempre nos olha, impondo um em, um dentro?" (DIDI-HUBERMAN, 1998, p.30).

A construção histórica da imagem faz com que ela se refira sempre à cópia da cópia, uma ilusão. Imagem é uma representação da coisa em si, não a coisa. Dessa forma podemos questionar: como os emoticons podem ultrapassar essa dimensão da imagem, sendo ao mesmo tempo código e visualidade?

Expandindo a noção de letramento, sabe-se que toda leitura é feita de imagens, lemos imagens como escrituras, essa dupla função, imagem e escrita tão evidente nos ideogramas orientais. Quando Foucault (1988) se remete à obra de René Magritte Ceci n'est pas une pipe, ele coloca imagem e palavra no mesmo nível, não havendo hierarquia entre elas, principalmente porque as duas se traduzem, pode-se tomar uma pela outra, se constituem no mesmo universo do conceito. Ambas, palavra e imagem, são visualidades que comunicam. Palavra é imagem, imagem é palavra em um intercâmbio em fluxo contínuo.

Foucault (1998) vai se referir ao caligrama em que a dimensão visual é a mesma da dimensão da escrita, valendo como signo imagético e semântico. As duas, imagem e palavra, estariam no mesmo lugar, criação de uma língua em comum. Assim, o caligrama pretende apagar ludicamente as mais velhas oposições de nossa civilização alfabética: mostrar e nomear, figurar e dizer, reproduzir e articular, imitar e significar, olhar e ler. Categoria essa que também expandimos para os emoticons.

O caligrama aproxima texto e figura, compõe com linhas que delimitam a forma do objeto juntamente com aqueles que dispõem a sucessão das letras, aloja os enunciados no espaço da figura e faz dizer ao texto aquilo que o desenho representa. O caligrama se serve dessa propriedade das letras que consiste em valer ao mesmo tempo como elementos lineares que se pode dispor no espaço e como sinais que se deve desenrolar segundo o encadeamento único da substância sonora. Sinal, a letra permite fixar as palavras; linha, que permite figurar a coisa. "Em sua tradição milenar, o caligrama tem um tríplice papel: compensar o alfabeto, repetir sem o recurso da 


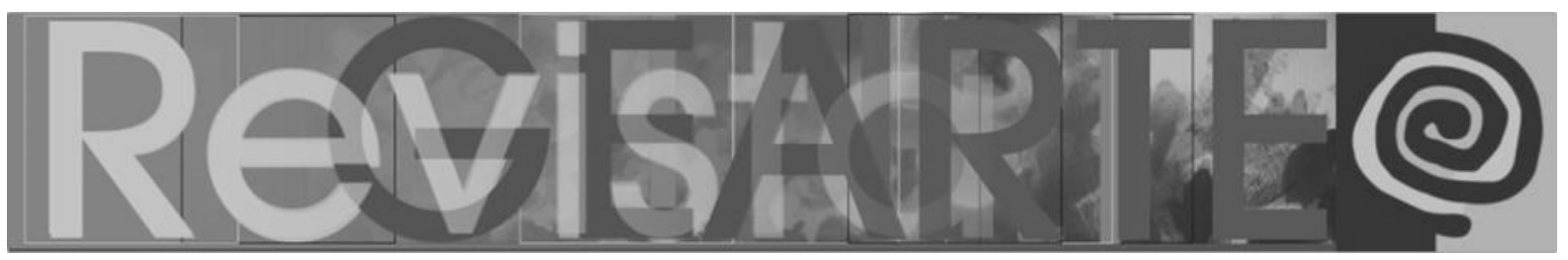

retórica, prender as coisas na armadilha de uma dupla grafia" (FOUCAULT,1988, p. 22).

Problematizando a ideia de imagem como mensagem, Marie-José Mondzain (2013) diz, ainda, que a imagem é a presença de uma ausência. O poder da imagem é aquele da palavra, um poder ambíguo e complexo. Ou seja, entre a saturação das imagens e da centralização dos discursos é preciso lutar contra a redução das imagens falantes à linguagem:

\begin{abstract}
A imagem, poderíamos dizer, é fenomenologicamente verdadeira. É a manifestação visível daquilo que fundamenta a verdade do olhar, posto que suscita não apenas nossos olhos da carne, porém o ardor e a paixão que os habitam na produção da verdade. Dirige-se a cada um de nós, àquilo que fundamenta nossa adesão á vida e ao pensamento como sendo uma coisa só (MONDZAIN, 2013, p. 92)
\end{abstract}

Esse olhar espreita à procura de entendimento dos discursos que emanam do texto imagético, indagando à representação visível acerca de seus significados invisíveis, desocultando traços de diálogos travados anteriormente, muitas vezes na sua elaboração. Nesse bojo, a autora sugere que "quer nos situemos no nível da imagem natural, quer no da imagem artificial, a imagem é sustentada por uma ideia do sentido, e não do signo" (MONDZAIN, 2013, p. 112).

Pensando o que diz Mondzain frente ao letramento visual e à leitura de imagens, o contexto é ponto fulcral e determinante nessa leitura, buscando para si uma significação muito mais concreta frente ao signo, que permanece solto e alijado na busca de interpretação. Assim, quando afirma que a sustentação da imagem está na "ideia do sentido", essa significação passa também pelo sentir, convertendo a comunicação em texto "decifrável" e, em se tratando da imagem, com uma multiplicidade de sentidos. A imagem é polissêmica por excelência.

Mondzain (2013) designa a invisibilidade do visível, suas relações de poder. Poderíamos criar a hipótese de que a invisibilidade da imagem, aquilo que não podemos enxergar na imagem seria tão importante como a própria imagem. A imagem como toda uma rede de constituições históricas, de reverberações ao longo da 


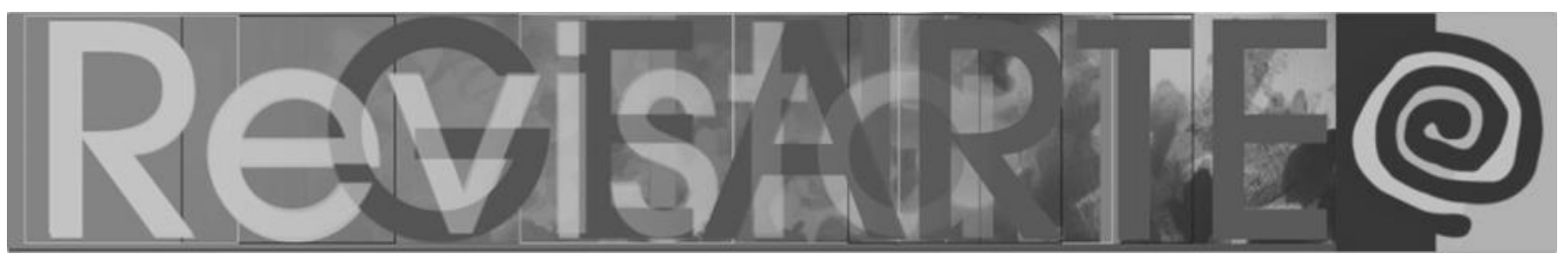

história: as vozes endereçadas a uma escuta. Entrar na experiência visual é arriscarse a não ver mais. Tornar-se a própria imagem. Para a autora, "é que a imagem atua, faz algo que o discurso não faz. [...] Pois se o discurso pudesse dizer tudo que a imagem é capaz de fazer, ele substituiria a imagem e teria sobre ela a superioridade de ser a sua teoria" (MONDZAIN, 2013, p.22).

Frente à citação anterior, a autora concilia a possível contenda entre a expressividade das palavras versus imagem, apontando que cada uma das linguagens não se opõe e, ao contrário, se complementam buscando a efetividade da/na comunicação. Assim, há discursos que comunicam e ainda, que se intercomunicam formando uma trama de vozes que soam e reverberam, palavra e imagem trocando mensagens incessantemente, muitas vezes, sem uma hierarquia nessa dialogicidade.

A noção de pós-imagem também está no bojo das discussões contemporâneas em que a linguagem dos emoticons não seja mais imagem no sentido filosófico requerido pela arte, algo que está além da visibilidade, algo que está na ausência, que não é comunicacional, que vai cindir com o discurso da imediaticidade; os emoticons surgem do pensamento do letramento visual, da construção de entendimento. Nesse tipo de comunicação as fronteiras entre a dialética da visibilidade/invisibilidade ficam borradas, esgarçadas, fragmentadas, pois o que está em jogo é a construção de uma linguagem, uma simbologia plural e universal. Há de se pensar até que ponto a concepção da imagem artística, por exemplo, tomada numa redoma de invisibilidades, vozes endereçadas a uma escuta previamente pensada, reitera a concepção de uma arte sacralizada, elitista e excludente, que não se faz acessível no terreno das Pedagogias Visuais.

Essas reverberações históricas formadas por sobreposições, por diversas camadas discursivas é que possibilita a emergência da imagem, que é também sua parte invisível. É por meio da imagem que se consegue comunicar algo, partilha do sensível: 


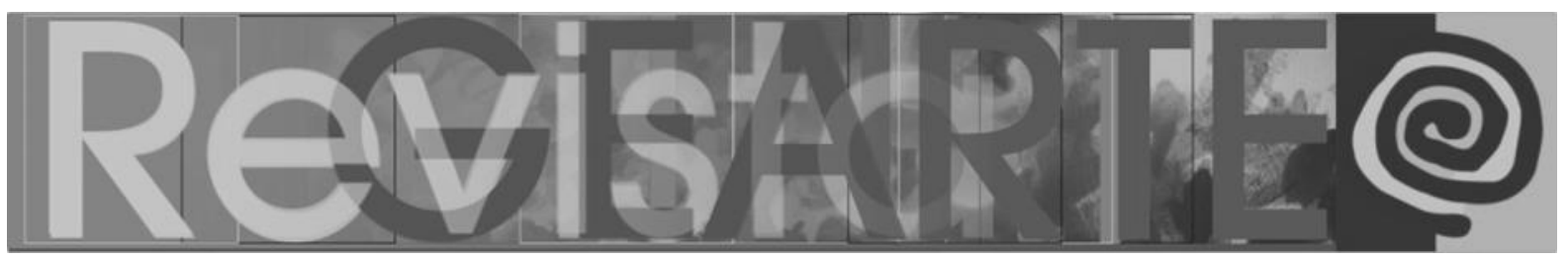

A partilha do sensível faz ver quem pode tomar parte no comum em função daquilo que faz, do tempo e do espaço em que essa atividade se exerce. Assim, ter essa ou aquela "ocupação" define competências ou incompetências para o comum, dotado de uma palavra comum etc. (RANCIËRE, 2005a, p. 16).

Sobre a pintura como partilha, o que também pode ser pensado frente às imagens dos emoticons, o autor se pronuncia dizendo que:

\footnotetext{
É na superfície plana da página, na mudança de função das "imagens" da literatura ou na mudança do discurso sobre o quadro, mas também nos entrelaces da tipografia, do cartaz e das arte decorativas, que se prepara uma boa parte da "revolução antirrepresentativa" da pintura (RANCIĖRE, 2005a, p. 22).
}

Essa revolução a que se refere Rancière parece anunciar a desestabilização das imagens como representações sacralizadas e instaurando novas formas de representação que não se cadenciam "puras", mas hibridizadas e fluidas, buscando uma contextualização das possibilidades de entendimento das mensagens, sem determinação do fluxo de leitura que se move na partilha com as múltiplas entradas e diversas sensibilidades.

Comunicar algo é, acima de tudo, entrar no terreno do visível, que se constitui também por toda invisibilidade coletiva e inconsciente. Aqui podemos fazer a distinção entre "imagem" e "mensagem": uma de aspecto intraduzível, tautológica, que se refere a si mesmo como um espelho. Por isso, recorremos ao termo visível/invisível de Mondzain (2013), e outra de aspecto comunicacional em que os emoticons fazem parte se constituindo de uma mensagem primária, simples, em que não há lugar para distinções. A mensagem seria direta, sem subterfúgios, exprimindo sua capacidade comunicacional, daí falar em letramento visual como a própria utilização social desses símbolos.

Os emoticons, foram criados na década de 1980 a partir de sinais de pontuação que, em seu conjunto, buscavam exprimir imagens de sentimentos ou marcar mensagens de textos com sinais que as identificasse como conteúdo específico. 


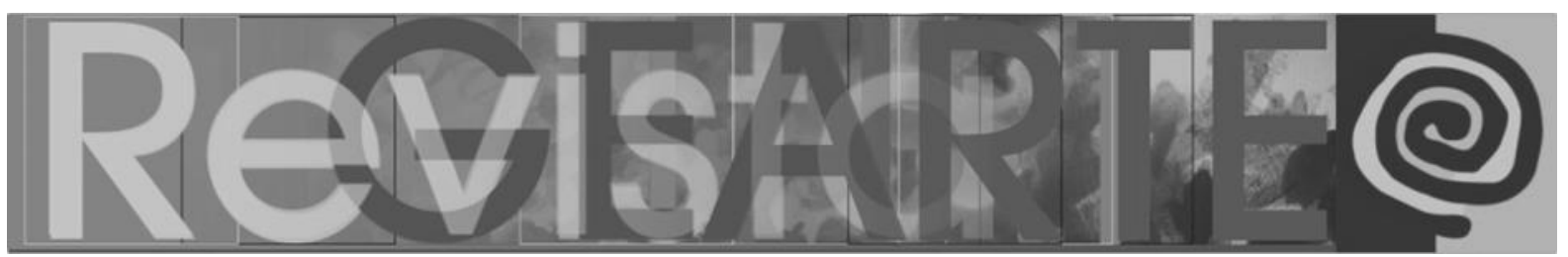

Segundo Freitas (2016), em texto no Jornal Nexo4, o episódio que marca a "invenção oficial" dos emoticons data de 1982 quando o professor Scott E. Fahlmann, da Universidade Carnegie Mellon, na Pensilvânia (EUA), buscando ser melhor compreendido nos quadros de recado da universidade (os BulletinBoards ou bboards), sugeriu que as mensagens irônicas fossem diferenciadas com sinais: ":-)" e ":-(".

Fato que se espalhou rapidamente e que somente foi reconhecido como invenção do professor Fahlmann quando, vinte anos mais tarde, um diretor da Microsoft empreendeu uma busca arqueológica para encontrar e recuperar a primeira mensagem que havia sido enviada com um emoticon. Interessante pensar que muitas imagens ancestrais também necessitam de buscas arqueológicas nos mais diversos terrenos - físicos ou virtuais, como se vê - para que se tornem (re)conhecidas, hibridizando mais uma vez a relação imagem-texto-imagem-palavra.

A origem da palavra emoticon surge da contração das palavras emotion (emoção) e icon (ícone), e, conforme definição de Júlio Araújo, em matéria de Jansen $(2012)^{5}$, "são recursos digitais semióticos de linguagem que servem para simular emoções, afetividade e gestos físicos durante uma interação em um ambiente virtual ou não". Ou seja, os emoticons fazem parte do campo mais amplo da semiótica como imagens que comunicam, que levam e trazem mensagens circulantes nas relação intra, inter e extrapessoais, enfatizando a imagem como formadora e veiculadora de discursos.

Porém, Freitas (2016) alerta em seu texto que há registros, em 1881, na revista estadunidense Puck de 1881, em um artigo com título Arte Tipográfica, mostrava

4 Matéria de Ana Freitas Você sabe qual é a história da invenção do emoticon? Aqui está ela ;-), no Jornal Nexo, de 30 de setembro de 2016. Disponível em: <https://www.nexojornal.com.br/expresso/ 2016/09/30/Voc\%C3\%AA-sabe-qual-\%C3\%A9-ahist\%C3\%B3ria-da-inven\%C3\%A7\%C3\%A3o-doemoticon-Aqui-est\%C3\%A1-ela>. Acesso em: 15 dez. 2016.

5 Matéria de Thiago Jansen Emoticon, a criação despretensiosa que teve sucesso na internet, no Jornal O Globo online, de 3 de abril de 2012. Disponível em: <http://oglobo.globo.com/sociedade/ tecnologia/emoticon-criacao-despretensiosa-que-teve-sucesso-na-internet4487061\#ixzz4bEsehPrX>. Acesso em: 15 dez. 2016. 


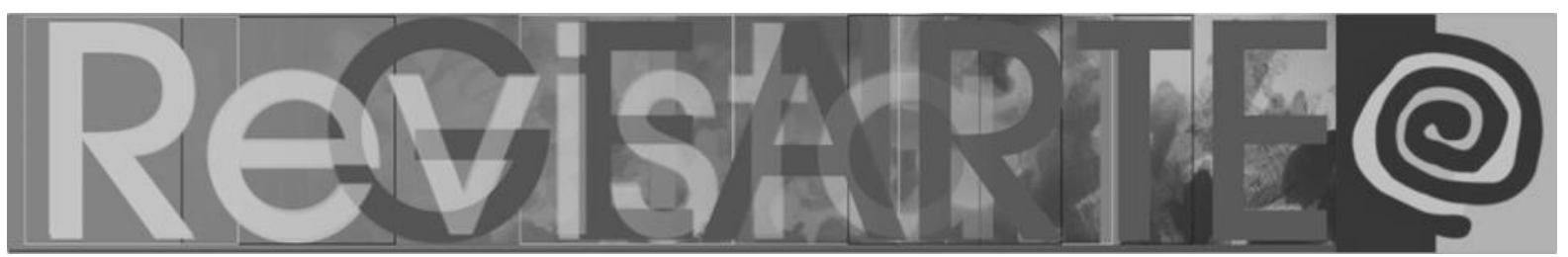

algumas expressões de humor utilizando sinais gráficos da máquina de escrever. Após esse primeiro registro, Freitas relembra que outro escritor dos Estados Unidos, Ambrose Bierce, sugeriu um "sorriso tipográfico" _ _ _ para que fosse utilizado em trechos irônicos, logo após a pontuação da frase. E ainda, no texto da matéria, a autora relata que o escritor russo Vladimir Nabokov apontou, em entrevista ao jornal The New York Times, a necessidade de expressões outras que fossem além das regras formais da escrita. Frente a essas ressalvas, observamos que a imagem, criada com sinais de pontuação ou não, ultrapassa e busca em alguns textos transpassar o escrito, buscando na imagem uma ampliação do que se quer dizer na letra escrita.

Essa perspectiva reforça o que vimos aqui debatendo, de que não há diferenciação dicotômica entre imagem e texto, pois palavra é também imagem. Longe de reducionismos, é importante ressaltar que na perspectiva do letramento visual a premissa é a da leitura e o uso social da imagem, sem deixar de pensar em letramento numa perspectiva mais ampla em seus diversos usos e discursos circulantes.

A esse respeito, Mondzain (2103, p.15) propõe reflexão quando aponta que:

\begin{abstract}
Em nosso século, a imagem encontra-se no cerne da preocupação que temos com a salvaguarda de nossa liberdade e de nosso pensamento. Posto que a invasão do planeta por um imperialismo visual e audiovisual reduz toda reflexão crítica e toda tomada da palavra a um estado de letargia servil e fascinação acéfala, convém compreendermos os elementos de uma genealogia cuja prole última tanto é portadora do melhor quanto do pior. Talvez não haja nenhum desastre em preparação, exceto aquele, sempre ameaçador, da demissão do pensamento. Mas a imagem não é responsável por isso; ela espera que pensemos à luz de sua história, bem como no cerne de sua vitalidade presente e esmagadora.
\end{abstract}

Frente ao que diz a autora, não é mais viável condenar a imagem a um papel secundário nos discursos que permeiam as relações humanas e muito menos condená-las a um papel de "guilhotinas", instrumentos que causam a "demissão do pensamento". Ao contrário, a autora parece convidar a que se pense esse "imperialismo visual e audiovisual" como formas de compreensão das múltiplas vozes e discursos na trama do tecido social, no qual todos falam, mas apenas algumas vozes são "ouvidas"... 


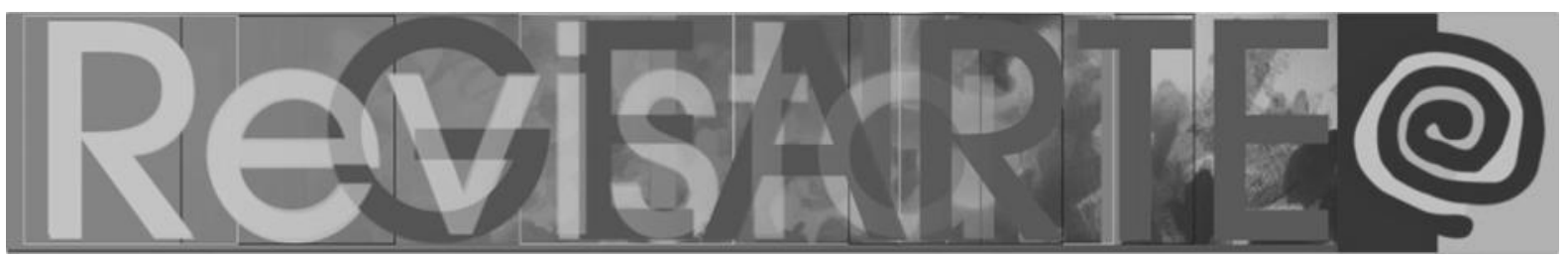

É interessante também pensar junto a essa leitura imagética o contexto no qual foram criados os emoticons, trata-se de um contexto que entra em cena mais fortemente as novas tecnologias de informação e comunicação (TICs), generalizando outro suporte comunicacional para além do suporte de mídias físicas: o virtual. Tangenciando o debate que envolve a questão dos suportes midiáticos de comunicação e indo adiante, a velocidade da comunicação também aumenta e, essa rapidez exige também formas de comunicação de imediato reconhecimento e entendimento, para uma resposta ligeira. Dessa forma, inserir sinais que de alguma forma aceleram o entendimento das mensagens torna-se um excelente recurso nessa comunicação cada vez mais veloz. $E$ as imagens têm excelência nesse processo.

Na década de 1980, quando Fahlmann utiliza sinais de pontuação para formar figuras, a tecnologia da época se mostrava incipiente no sentido da programação e dos suportes informáticos. Entretanto, com o desenvolvimento e a chegada de novos recursos de programação, esses sinais foram sendo convertidos em imagens cada vez mais elaboradas, com nuances nas expressões e cores utilizadas.

Não parece ser coincidência que é também a década de 1980 que marca a entrada dos estudos de letramento no Brasil, conforme relata Soares (2009) no livro Letramento: um tema em três gêneros. A autora relata que Mary Kato foi uma das primeiras a utilizar o vocábulo em referência de que a língua culta é consequência do letramento em 1986. Soares traz a etimologia da palavra letramento vindo do latim littera - letra, com o sufixo cy- qualidade, estado. Conforme Soares (2009, p.17), litteracy "é o estado ou condição que assume aquele que aprende a ler e a escrever". Ao longo do texto, a autora vai ampliando o conceito, enfatizando que o sujeito letrado é aquele que faz uso social da leitura e da escrita, lidando com múltiplos textos, dentre esses, os textos imagéticos, ponto central desse estudo.

Buscar entendimento dos emoticons como parte dos processos de letramento visual é pensar a imagem em sua dimensão de plena comunicação, coletiva e individual. Nesse sentido, ler imagens é também pôr em uso a prática social da leitura 


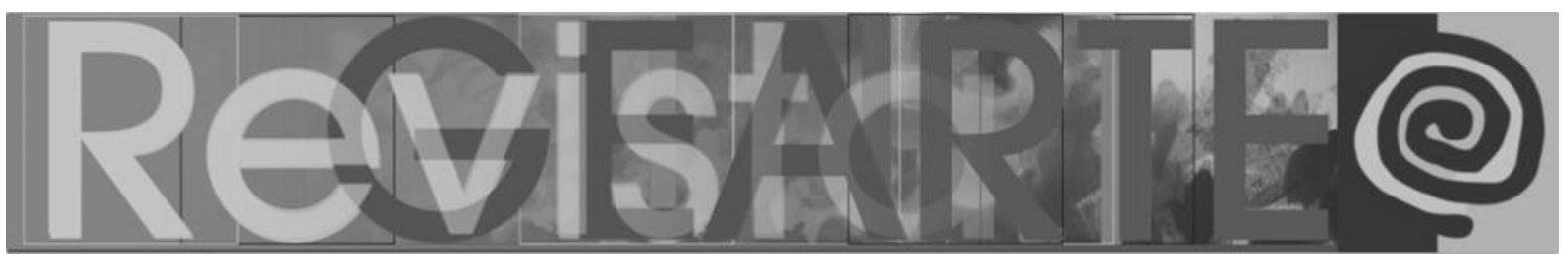

e escrita, como uma pedagogia da imagem quase que implícita na própria utilização de figuras e símbolos tais como emoji/emoticons. Entender o letramento visual como práticas discursivas, com gêneros e suportes diversificados, amplia a compreensão dos processos de alfabetização para além do ensino aprendizagem dos códigos escritos, situando essas práticas nas relações do cotidiano e atribuindo a estas o grau de importância na inserção da vida pública e no exercício dos direitos de cada um e coletivamente.

\section{Referências}

AUMONT, J. A imagem. Campinas, São Paulo: Papirus, 2000.

FOUCAULT, Michel. Isto não é um cachimbo. Rio de Janeiro: Paz e Terra, 1988.

KLEIMAN, A. Os significados do letramento. Campinas: Mercado das Letras, 1995.

DIDI-HUBERMANN, Georges. O que vemos, o que nos olha. São Paulo: Editora 34, 1998.

MONDZAIN, Marie-José. Imagem, ícone, economia. Rio de Janeiro: Contraponto/ Museu de Arte do Rio, 2013.

FREITAS, Ana. Você sabe qual é a história da invenção do emoticon? Aqui está ela ;-). In: Nexo jornal. Disponível em:

<https://www.nexojornal.com.br/expresso/2016/09/30/Voc\%C3\%AA-sabe-qual-\%C3\%A9-ahist\%C3\%B3ria-da-inven\%C3\%A7\%C3\%A3o-do-emoticon-Aqui-est\%C3\%A1-ela>. Acesso em: 15 dez. 2016.

JANSEN, Thiago. Emoticon, a criação despretensiosa que teve sucesso na internet. In: Jornal O Globo online, de 3 de abril de 2012. Disponível em: <http://oglobo.globo.com/sociedade/tecnologia/emoticoncriacao-despretensiosa-que-teve-sucesso-na-internet-4487061\#ixzz4bEsehPrX>. Acesso em: 15 dez. 2016.

RANCIÈRE, Jacques. A partilha do sensível: estética e política. São Paulo: EXO/34, 2005 a.

RODRIGUES, Walace. Letramento visual em classes de licenciatura em pedagogia/PARFOR. Revista Didática Sistêmica, v. 17, n. 1, p. 83 - 94, 2015. Disponível em: <https://www.seer.furg.br/redsis/ article/viewFile/5466/3579>. Acesso em: 30 set. 2016.

SARDELICH, Maria Emília. Leitura de imagens e cultura visual: desenredando conceitos para a prática educativa. Educar, Curitiba, n. 27, p. 203-219, 2006.

SOARES, Magda. Letramento e alfabetização: as muitas facetas. In: 26 $6^{\underline{a}}$ Reunião Anual da ANPEd. Poços de Caldas, 2003. Disponível em: <http://www.scielo.br/pdf/rbedu/n25/n25a01.pdf>. Acesso 15 set. 2016.

SOARES, Magda. Letramento: um tema em três gêneros. Belo Horizonte: Autêntica, 2009.

VILCHES, Lorenzo. La lectura de la imagen. Prensa, cine, televisión. Barcelona: Paidós, 1984. 


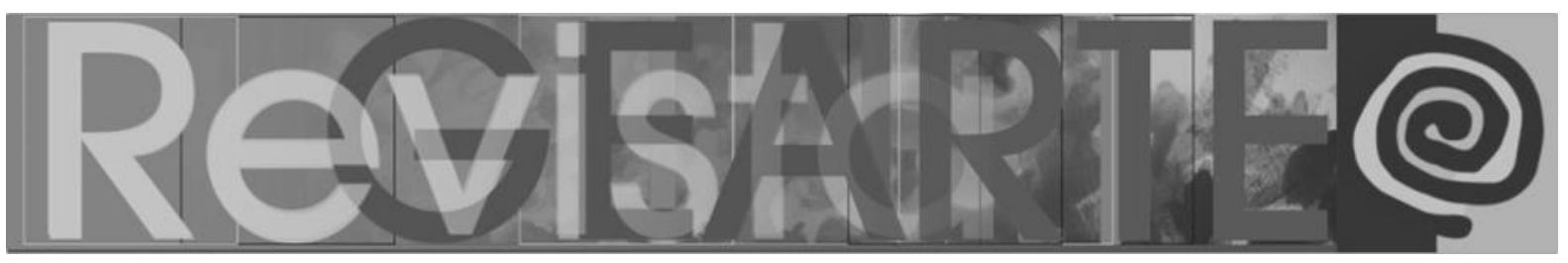

\section{Ana Valéria de Figueiredo da Costa}

Doutora em Ciências Humanas-Educação pela PUC-Rio e Mestre em Educação pela PUC-Rio. Professora Adjunta da UERJ no Instituto de Artes; Pesquisadora do Diretório de Pesquisa Jovens em Rede PUC-Rio. Coordenadora de Iniciação Científica do Curso de Pedagogia da Universidade Estácio de Sá. Especialista em Mediação Pedagógica em EAD pela PUC-Rio. Especialista em Gestão da Escola Pública pela UFJF. Especialista em Educação Especial pela Universidade Iguaçu. Especialista em Arte-terapia, Educação e Saúde pela Universidade Candido Mendes. Especialista em Planejamento, Implementação e Gestão da EAD pelo LANTE/UFF. Especialista em Diversidade Étnica e Educação Superior pela UFRRJ. Professora da especialização lato sensu dos cursos de Arte Educação, Psicopedagogia Clínica e Institucional, Educação Especial e Docência do Ensino Superior da Universidade Iguaçu. Professora Docente do Curso de Pedagogia e Licenciaturas da Universidade Estácio de Sá e da Universidade Iguaçu.

E-mail: anavaleria.figueiredo@yahoo.com.br

Currículo: http://lattes.cnpq.br/6434170770324585

\section{Isabel Almeida Carneiro}

Artista visual e professora Adjunta do Instituto de Artes da UERJ no departamento de Ensino da Arte e Cultura Popular. Atua nas áreas das artes e educação. Uma das coordenadoras do PIBID (Programa institucional de Bolsa de Iniciação à Docência) sub-projeto Artes- UERJ. Licenciada em Artes Visuais pelo Centro Universitário Barra Mansa. Especialista pela PUC-Rio em História da Arte e da Arquitetura no Brasil. Mestre pelo Programa de Pós-graduação em Artes da UERJ. Doutora pelo PPGAV/EBA/UFRJ na linha de Linguagens. Realizou parte de sua pesquisa de tese na Paris 1Sorbonne de setembro de 2013 a agosto de 2014 com o auxílio da bolsa sanduíche da CAPES onde expandiu a noção entre visualidades e sonoridades através da forma-partitura. Atuou como professora de artes do ensino fundamental $2^{\circ}$ ciclo no Município de Nova Iguaçu de 2009 a 2012. E como professora substituta no Instituto Federal-RJ no ano de 2015 lecionando oficinas de pintura e monotipia.

E-mail: bebelcarneirogm@gmail.com

Currículo: http://lattes.cnpq.br/4988281259224394

Recebido em 21 de dezembro de 2018 Aceito em 17 de abril de 2019 